applied science which, largely through his initiative and vision, has developed beyond all expectations. The idea of having a scientific laboratory in an archæological museum was entirely novel, when, in 1919, the trustees of the British Museum sent a request to the Advisory Council for Scientific and Industrial Research for assistance in connexion with problems of cleaning, restoring and preserving antiquities. That Dr. Scott was called in to advise was singularly fortunate. His wide knowledge of chemistry coupled with his interest in antiquities fitted him peculiarly for the work. Within seven years the original inquiry had been satisfied and the results published in three reports which aroused widespread interest. Early experiences were of incalculable value when he visited Luxor and cooperated with Dr. Howard Carter in preserving many valuable objects from the tomb of Tut-ankhAmun. As experience accumulated, the fact emerged that scientific assistance could be of much greater value to archæology and the British Museum in general than had been at first supposed. There were questions of authenticity, of the composition of materials, of ancient technique, of classification, and of general diagnosis that could be answered only with the help of qualified scientific staff having the necessary facilities. Dr. Scott has had the satisfaction of founding and controlling the development of a research laboratory which from small beginnings became at length (in 1931) incorporated as a department of the British Museum, and is recognized to-day as being of the first importance by archæologists and museums the world over.

\section{Rejoinder of an Egg Collector}

To Mr. Edgar P. Chance all credit is due for his film of cuckoo life, which thrilled every ornithologist who saw it and made a distinct contribution to scientific knowledge. This achievement, however, does not necessarily justify all his other activities, and for his egg-collecting he has been severely criticized. His rejoinder appears as an eight-page pamphlet entitled "An Egg-Collector Replies to his Critics" (Sept. 1938). In our view, an appropriate reply would be to show that the amount of disturbance caused to wild birds was justified by the amount and value of the scientific knowledge gained from the collections and published for the information of other scientific workers. Unfortunately, this reply makes no attempt at such justification, and is marred by expressions which cannot further the case of the egg-collector. The author's ethics are hinted at in a paragraph which states that "Bird Protection laws are proverbially stupid [we have not heard any proverb on the subject] . . . When a law is not worthy of respect it ceases to be law to those who know better". That is a position which cannot be defended, any more than can be the allegation that the bird protection laws are framed "by those who do not understand their subject". Clearly, however, the collector is himself convinced that his collection, which "is complete and only the abnormal can now find a place there", has been brought together without any unwonted disturbance of the numbers or distribution of wild birds.

\section{Accessions to the British Museum (Bloomsbury)}

Among the accessions to the British Museum (Bloomsbury) reported at the meeting of the trustees on October 8 (the first meeting to be held after the recess) were a number of antiquities from Central America, part of the collection made by the late Mr. T. W. Gann, and bequeathed by him to the Museum. They were accepted by the trustees in May last, but this selection has been received at the Museum only recently. The more important specimens are a number of carved jades, including figures of men and animals, coming mostly from Copan in Honduras. The best example is a magnificent green jade plaque with figures carved in relief. It is said to be the finest known example of carved jade from Central America. It was found at Teotihuacan in Mexico, but is thought to have come originally from Quiriqua in Honduras. By its style it is assigned to the Old Empire of the Maya, and dates probably from the fifth century A.D. In addition the bequest includes a number of fantastically shaped flints of unusual size. Some of these range up to seventeen inches long. There are also a number of painted stucco heads, with elaborate headdresses and some beautiful examples of the Mayan painted pottery. Another accession to the American collections obtained by purchase is an archæological collection from Esmeraldas Province, Ecuador, while an anonymous loan consists of a notable series of antiquities from mexico, which includes a remarkable series of funerary urns in human shape from Oaxaca. The Museum has now received its share of the antiquities found by Sir Leonard Woolley and Mr. M. E. L. Mallowan on their respective expeditions in Northern Syria, which were conducted under the auspices of the Museum jointly with the School of Archæology in Iraq. Grants have been allocated for the renewal of both these expeditions in 1938-39.

\section{Excavations in Northern Syria}

Mr. M. E. L. MaLLOWAN's expedition to the Habur region of Northern Syria in the spring of 1938, from which came the finds to which reference is made above, excavated four areas, which in conjunction yielded evidence covering a period extending from 3100 B.c. down to 1500 B.C. The remains latest in date were Hurrian houses of mud-brick in three successive levels, ranging in date from 1800 B.c. to 1500 B.c. These yielded a quantity of pottery of white design on black. Some private houses, Mesopotamian in plan, were contemporary with the third dynasty of Ur; but the most important evidence was obtained from the Sargonid level with its Akkadian palace, and the ziggurat, or tower, of Jemdet Nasr date, of which the remains were found beneath the Palace. The Palace, of which a complete ground plan was recovered, is a huge building, 90 metres by 90 metres, ranged about a great courtyard. It was built, as is shown by an inscription, by Naram Sin, son of Sargon, about 2500 B.c. It was destroyed by fire approximately at the end of the Sargonid period and rebuilt under the third dynasty of Ur. Below the south-west corner of the Palace were the ruins of a great tower, which was built 